\title{
The value of added sulfur dioxide in French organic wine
}

Kelly A Grogan

Correspondence:

kellyagrogan@ufl.edu

Food and Resource Economics,

University of Florida, PO Box

110240, Gainesville, FL 32611, USA

\begin{abstract}
The addition of sulfur dioxide is a longstanding and common practice in the winemaking industry. Sulfur dioxide preserves wine, preventing oxidation and browning. However, in the U.S., wine labeled as organic cannot contain added sulfur dioxide. A petition put forth to the National Organic Standards Board for the allowance of added sulfur dioxide in organic wine was recently rejected. In France, added sulfur dioxide is allowed in organic wine, but not used in all organic wine. This variation in use allows the estimation of the value of added sulfur dioxide in French organic wine, which sheds light on the possible benefits of a policy change in the U.S. For red wines, the addition of sulfur dioxide reduces the suggested retail price of wines to be consumed immediately after purchase, but the effect becomes positive for wines that are intended to be cellared for at least one to three years before consumption. The effect for most white wines is neutral to positive. The magnitude of the effect for both red and white wines varies by eco-certification type.

JEL codes: Q13; Q18

Keywords: Eco-Label; Hedonic Price Analysis; Organic Wine; Sulfites; Sulfur Dioxide
\end{abstract}

\section{Background}

The addition of $\mathrm{SO}_{2}$ in wines is a longstanding and common practice utilized to preserve the quality of wine by preventing oxidation and browning. However, the practice has received attention in recent years due to variations in organic regulations across countries and the general public's perceptions of the health effects of added $\mathrm{SO}_{2}$. In the U.S. wine market, the addition of $\mathrm{SO}_{2}$ is not allowed for wines labeled as "organic" wine. Wines with this addition that would otherwise meet the requirements to be labeled as organic, must instead be labeled as "made with organic grapes" (Alcohol and Tobacco Tax and Trade Board 2014). In 2010, several wineries and vineyards petitioned the National Organic Standards Board (NOSB) to allow the addition of $\mathrm{SO}_{2}$ in wine labeled as "organic", citing misunderstandings among consumers about the "made with organic grapes" label and the allowance of added $\mathrm{SO}_{2}$ in wines labeled as organic in Europe and Canada as their primary reasons for petitioning for the change. The petition was rejected at the NOSB meeting in November 2011 (Siegel 2010, National Organic Standards Board 2011a). This paper determines the effects of adding $\mathrm{SO}_{2}$ on the price of French organic wine, thereby providing potential monetary effects of the current U.S. policy that prevents the addition of $\mathrm{SO}_{2}$ to organic wine.

\section{Springer}


This paper does not attempt to claim that $\mathrm{SO}_{2}$ should or should not be allowed in wine labeled as organic; it only seeks to determine if U.S. winemakers could receive a higher price if allowed to add $\mathrm{SO}_{2}$ to wine labeled as organic. This information is beneficial to policymakers and the National Organic Standards Board to determine monetary effects of their policy as well as to organic winemakers to determine whether continued perseverance on this matter is worthwhile. This paper proceeds as follows. First, background information on the addition of $\mathrm{SO}_{2}$ to wine is provided. The second section contains a summary of previous work, and the third presents theoretical and empirical models. A discussion of the dataset follows the models, and then results and conclusions are presented.

There are two potentially conflicting effects of $\mathrm{SO}_{2}$ on wine price. First, there is the "red wine headache" myth. For some people, red wine causes headaches, and these headaches are often blamed on sulfites (Gaiter and Brecher 2000). American and French consumers of wine hold this belief (Remaud and Sirieix 2012). However, studies suggest that histamines and biogenic amines are the actual culprits (Jarisch and Wantke 1996). If consumers prefer red wines without added $\mathrm{SO}_{2}$ due to the misperception that sulfites cause their headaches, then sulfured red wines would be expected to receive a lower price than unsulfured, ceteris paribus. It should be noted that for a small portion of people (less than $0.05 \%$ ), sulfite consumption can cause reactions ranging from minor skin, respiratory, or gastrointestinal problems to anaphylactic shock and even death (Lester, 1995). The possibility of severe reactions from consumption of sulfites has resulted in warning labels on wines containing more than $10 \mathrm{ppm}$ of sulfites (Alcohol and Tobacco Tax and Trade Board [ATTTB] 2006). For this sulfite-sensitive segment of the population, both the red wine headache myth and the sulfite sensitivity would affect price.

The second possible effect of $\mathrm{SO}_{2}$ on wine price is positive and may counteract the effect of the headache myth. $\mathrm{SO}_{2}$ is an antioxidant and removes quinones (organic compounds) from the wine that, if not removed, would eventually lead to browning, oxidation, and spoiling of the wine. Such spoilage, however, may not occur immediately (Waterhouse 2002). Since there is a time element to the prevention of spoilage, wines consumed immediately after purchase will be less prone to spoiling, and the negative effect of $\mathrm{SO}_{2}$ may dominate. However, for consumers who purchase wines as an investment to be consumed in the future, the addition of $\mathrm{SO}_{2}$ may be quite valuable. It should be noted that $\mathrm{SO}_{2}$ is a relatively inexpensive input.

Using a dataset of 546 French organic wines, this paper tests whether and how the addition of $\mathrm{SO}_{2}$ affects the price received for organic wine. Results demonstrate that producers who produce wines that are meant to be cellared for an extended period of time experience a suggested retail price premium from the addition of $\mathrm{SO}_{2}$. However, those producers who produce red wines meant to be consumed soon after purchase actually experience a reduction in price from the addition of $\mathrm{SO}_{2}$, consistent with the red wine headache effect.

\section{Previous work}

Only one peer-reviewed paper addresses consumers' willingness to pay for wine labeled with "no sulfites added" (Costanigro et al. 2014). They find a price premium of $\$ 0.64$ 
per $0.75 \mathrm{~L}$ bottle for no sulfite-added wine in the U.S. market. Respondents who report experiencing headaches after consuming wine drive this result. When the sample is separated into headache sufferers and non-headache sufferers, their respective willingness to pay for no sulfites added are $\$ 1.23$ and $\$ 0.33$. These results would suggest that consumers would pay less for bottles of wine with added $\mathrm{SO}_{2}$ and that regulations preventing organic growers from adding $\mathrm{SO}_{2}$ are not resulting in lowered prices. However, this survey asked respondents about their experiences with headaches after drinking wine, and then proceeded to give them choice experiments with bottles labeled with organic, no sulfites added, and/or no special label. Such an ordering may have led respondents to attach a larger negative association to sulfites than they may attach to sulfites when actually purchasing wine.

While not specifically analyzing the effect of added $\mathrm{SO}_{2}$, Mueller et al. (2010), analyze the effect of various back label information on consumers' willingness to pay for wine. One of the attributes considered was an ingredient label that read: "Grapes, Sulphur dioxide, Yeast, Diammonium phosphate, Bentonite, Pectinolytic enzymes", versus labels that did not have any ingredients listed. The survey included choice experiments for which respondents had to choose one bottle to hypothetically purchase from among four options that varied in terms of the information provided on the back label. The inclusion of the ingredient list negatively affected the probability that a consumer chose the bottle for about a third of respondents. For $13 \%$ of the sample, the probability of choosing the bottle dropped by $59 \%$ with the inclusion of the ingredient list. Unfortunately, the effect of $\mathrm{SO}_{2}$ 's inclusion in the list cannot be separated from the effect of the other ingredients.

Work by Delmas and Grant (2010) indirectly touches on the topic of valuation of added $\mathrm{SO}_{2}$. They analyze the value of eco-certification and eco-labeling for California wines. Two forms of eco-certification were possible for the wines in their sample: certified organic and certified biodynamic. Among wines certified as organic or biodynamic, some contained eco-labels indicating the eco-certification of the wine, while others were eco-certified but not labeled as such. They find that eco-certification is associated with an increased price received for the wine, while eco-labeling results in a lower price. They posit that these findings might be due to confusion caused by the twotiered organic labels and due to the instability of wines produced without added $\mathrm{SO}_{2}$ over time.

In addition to work that directly or indirectly examines the effects of added $\mathrm{SO}_{2}$ on price and consumer decisions, other work establishes that consumers make wine decisions based on information on the front and back labels. Charters et al. (1999) analyzed consumers' perceptions and usage of back label information when purchasing wine, using a survey of people enrolled in wine courses in South and Western Australia. They found that $78 \%$ of respondents found the back label information "interesting" while $57 \%$ regularly used the back label information when making their wine purchase decisions.

Thomas and Pickering (2005) analyze the importance of wine information on purchase decisions, comparing New Zealand consumers who are 21 to 40 years old and those who are 41 years old or older. Among the survey respondents, the younger cohort placed a higher importance on the wine's attributes and the winemaking process than the older cohort. This suggests that younger wine drinkers may pay more attention to and care more about the addition of $\mathrm{SO}_{2}$ when choosing wines. 


\section{Methods}

To establish an effect of $\mathrm{SO}_{2}$ on price, the relationship between $\mathrm{SO}_{2}$ content and market price must first be established. For an individual, the maximum amount he is willing to pay for a bottle will be equal to the dollar value of the utility that he expects to receive from consuming the bottle. His expected utility, $E U$, from bottle of wine $i$ can be modeled as:

$$
E U_{i}=f(\text { taste }, \text { quality })(1-\beta(S, t))-\theta \gamma(S)
$$

where $\beta$ is the probability that the wine has spoiled, $S$ is the $\mathrm{SO}_{2}$ content of the wine, $t$ is the intended cellaring time, $\theta$ is the disutility experienced from a post-wine consumption headache, and $\gamma$ is the probability that the consumer experiences a headache after consuming the wine. It is assumed that utility is derived from the taste and quality of the wine, and that in the event of spoilage, the consumer gets no utility from the wine. Additionally, disutility from experiencing headaches is independent of the initial utility derived from the wine's taste and quality.

The probability of spoilage, $\beta$, is a function of added $\mathrm{SO}_{2}$ and cellaring time where the addition of $\mathrm{SO}_{2}$ decreases $\beta$ and increased cellaring time increases $\beta$. The probability of a headache, $\gamma$, should be independent of $\mathrm{SO}_{2}$ content, but some consumers may perceive a positive effect of $\mathrm{SO}_{2}$ content on $\gamma$. While bottles rarely contain the exact sulfite content, different ecolabels have different maximum allowed concentrations, and most bottles that do not have added $\mathrm{SO}_{2}$ contain a label saying so. A consumer who is concerned about consumption of sulfites can consume a wine with no added sulfites or a lower concentration of sulfites and may pay a price premium in order to do so, as demonstrated by Costanigro et al. (2014). A consumer concerned with spoilage will likely not prefer such wines and may pay a price premium for wine with added $\mathrm{SO}_{2}$.

When a consumer purchases a wine they have previously not tasted, they will need to rely on attributes of the wine to determine the expected taste and quality of the wine, $f$ (taste, quality) in (1). Four classes of attributes are considered: indirectly observable wine characteristics, directly observable wine characteristics, measures of wine quality, and winery characteristics. Indirectly observable wine characteristics arise from production practices. These could be flavors that result from aging in an oak barrel or sweetness that arises from adding sugar to the wine. ${ }^{1}$ For a consumer purchasing a wine that they have not consumed before, they have some idea of what these production practices contribute to the wine without knowing exactly what they contribute to the specific wine. There are wine characteristics that are directly observable such as the percent alcohol, the variety, the wine region, and the vintage. Third, there are subjective measures of quality such as references in wine guides, Robert Parker ratings, and Grand Cru designations. Finally, there are characteristics of the winery that may influence a consumer's valuation of the wine. These could include certification by the Fédération Nationale Interprofessionnelle des Vins de l'Agriculture Biologique (FNIVAB), a private organic-certifying agency in France, which may increase value for consumers concerned about purchasing certified organic products. They could also include the size of the winery or the popularity of the winery. Finally, the inclusion of $\mathrm{SO}_{2}$ will influence the expected utility of the wine through the two mechanisms discussed above.

A major question that might arise is, "Do all consumers care about added $\mathrm{SO}_{2}$ or even notice if $\mathrm{SO}_{2}$ is added or not?" Most likely the answer to this question is no, but 
restrictions on $\mathrm{SO}_{2}$ will affect winemakers even if only a portion of consumers care about added $\mathrm{SO}_{2}$. Total market demand is the summation of the individual consumers' willingness to pay, and total market demand determines market price. Consider wine 1 that contains $\mathrm{SO}_{2}$ versus wine 2 that does not; the two wines are otherwise identical. Consumer group A believes that $\mathrm{SO}_{2}$ in wine gives them headaches while consumer group $\mathrm{B}$ completely disregards $\mathrm{SO}_{2}$ when purchasing a wine. Consumer group A's willingness to pay for wine 1 is less than its willingness to pay for wine 2, while group $B$ has equal willingness to pay across the two wines. When the individual demands are summed, the market demand and price for wine 1 will be less than that for wine 2 due to consumer group A's preferences.

In cases where market price and the characteristics of a good are known, hedonic pricing models can be employed to empirically determine the effect of the good's attributes, such as added $\mathrm{SO}_{2}$, on market price (Lancaster 1966, Rosen 1974). These models have been used extensively in the wine economics literature to determine the effects of quality ratings, climate change, terroir, objective and sensory wine attributes, cellaring potential, spatial externalities, and other wine attributes on wine price (see Ashenfelter and Storchmann 2010; Costanigro et al. 2007; Combris et al. 1997; Cross et al. 2011 Lecocq and Visser 2006; Viana and Rodrigues 2007; Yang et al. 2012 for examples). The price a consumer is willing to pay for a bottle of wine will equal their expected utility from consuming the bottle of wine, as modeled in equation (1), and the market price that will result in equilibrium will be an aggregation of all consumers' willingness to pay. Thus, following the theoretical model in equation (1), the bottle price of wine $i$ from winery $j, P_{i j}$, can be empirically modeled using an hedonic pricing model as:

$$
P_{i j}=\beta_{1}{ }^{\prime} I_{i j}+\beta_{2}{ }^{\prime} D_{i j}+\beta_{3}{ }^{\prime} Q_{i j}+\beta_{4}{ }^{\prime} W_{j}+\beta_{5}{ }^{\prime} S_{i j}+u_{j}+\varepsilon_{i j}
$$

where $I_{i j}$, is a vector of indirectly observable characteristics resulting from production practices, $D_{i j}$ is a vector of directly observable characteristics, $Q_{i j}$ is a vector of measures of quality, $W_{j}$ is a vector of winery characteristics, $S_{i j}$ is a vector of variables pertaining to $\mathrm{SO}_{2}$ use, $u_{j}$ is a normally distributed unobservable term associated with winery $j$, and $\varepsilon_{i j}$ is a wine-specific unobservable term for winery $j$ 's wine $i$ that is also normally distributed. ${ }^{2}$ Using linear regression, the coefficients can be estimated to determine the effect of each characteristic on price. The effects of added $\mathrm{SO}_{2}$ on price can be determined from the vector $\beta_{5}$.

Equation (2) could be estimated using Ordinary Least Squares (OLS), but this model may suffer from endogeneity, resulting in biased estimates of $\beta_{\mathrm{i}}$, if there are unobserved variables that affect both price and any of the independent variables. Unobservable characteristics such as terroir, the winery's natural endowments such as slope and microclimate, the talent of the winery's winemaker, and the winery's overall quality may affect the price received but they may also affect the choice of production technologies and hence the indirectly observable characteristics. In the dataset, the majority of wines have only one year separating their oldest and newest reported vintages, and the average span of vintages is only 1.9 years. ${ }^{3}$ While the winemaker may change during this span, wineries tend to hire winemakers of a similar quality, and changes in vineyard quality do not change substantially within small time periods (Reuter 2009). Consequently, all of the problematic unobservable characteristics are most likely at the winery level and constant within the observed timeframe; they will be controlled for by 
including a winery-level fixed effect, $u_{j}{ }^{4}{ }^{4}$ Previous work has made similar assumptions pertaining to the consistency of these winery-level unobservable variables across time (Ali and Nauges 2007; Delmas and Grant 2010; Haeger and Storchmann 2006).

$\varepsilon_{i j}$ likely contains shocks such as favorable or unfavorable weather for that particular wine's growing season, natural variation in the outcome resulting from the winemaking process, and other individual wine-specific shocks, which will be independent of the observed independent variables.

Equation (2) is empirically estimated using several sample groupings. The first includes all wines in one sample. This pooled sample may produce insignificant coefficients for some variables due to differing effects of practices and characteristics on the valuation of red versus white wines. The effect of added $\mathrm{SO}_{2}$, however, will be differentiated for red and white wines due to the interaction of the $\mathrm{SO}_{2}$ and white and rosé wine variables. This pooling has the advantage of the largest sample size. The second grouping splits the sample into two groups: white and red wines. Coefficients most likely vary across the two groups, but this division limits the sample size, particularly for white wines.

Since winemakers may add $\mathrm{SO}_{2}$ to wines of higher quality or to wines that will be sold at a higher price, this possibility is explored. First, a probit model of the probability of adding $\mathrm{SO}_{2}$ to the wine is estimated. The binary variable, $S_{i j}$, is observed, where $S_{i j}$ equals one if $\mathrm{SO}_{2}$ is added and zero otherwise. However, this binary variable is determined by the latent variable $S_{i j}^{*}$ which is the difference in expected profits between a wine with and without added $\mathrm{SO}_{2}$. The relationship between the observed and latent variables is given by:

$$
S_{i j}= \begin{cases}1 & \text { if } S_{i j}^{*}>0 \\ 0 & \text { if } S_{i j}^{*} \leq 0\end{cases}
$$

and the latent variable is modeled as:

$$
S_{i j}^{*}=\beta_{1}{ }^{\prime} I_{i j}+\beta_{2}{ }^{\prime} D_{i j}+\beta_{3}{ }^{\prime} Q_{i j}+\beta_{4}{ }^{\prime} W_{j}+\varepsilon_{i j}
$$

where all variables are as defined previously. Production variables and wine characteristics may affect the need for $\mathrm{SO}_{2}$. Wine price and wine price interacted with white and rosé indicator variables; indicators of quality; and winery characteristics may influence the winery's decision. Additionally, the model includes controls for wine variety, region, and vintage. From these estimates, possible sources of bias are identified. The most likely source of bias is due to a correlation between quality, which may be imperfectly measured with the variables utilized, and the addition of $\mathrm{SO}_{2}$. To test for this possibility, the data are grouped based on two indicators of quality: the AOC certification and whether or not the winery has ratings in the Parker database. Within these groupings, there will be less variation in quality and consequently a smaller likelihood that the results are simply picking up this correlation.

\section{Data}

While a European standard exists for organic grapes, until recently, no European standard existed for organic wine. The new standard, set by Regulation (EU) No. 203/2012 was implemented for the 2012 harvest, and this paper only makes use of wines 
produced prior to implementation. ${ }^{5}$ Due to the previous lack of a uniform standard, individual countries, producers and/or organic certifiers created their own standards for organic winemaking. Additionally, international organizations such as Demeter certify wine that meets their production standards. ${ }^{6}$ While maximum levels of permissible $\mathrm{SO}_{2}$ vary across these standards, all of the European (past and present) and international standards allow the addition of some $\mathrm{SO}_{2}$, and most limits on its use meet or exceed the limits used in the U.S. for wine labeled as "made with organic grapes" (Table 1) (Jonis et al. 2008).

This paper uses a dataset compiled from http://www.organic-wine.bien-boire.info/ index.php. This website contains information on French organic wines provided directly from the wineries. As a result, the sample may not be entirely representative of French organic wine. The sample likely includes wineries whose owners or employees are more technologically savvy or wineries that seek out free methods of disseminating information about themselves. There is no apparent way in which these types of wineries will differ with respect to $\mathrm{SO}_{2}$, so the results should still be generally applicable, despite the potential for an unrepresentative sample. As of March 2012, the website contained complete price, wine, and winery information for 546 wines.

Tables 2 and 3 provide summary statistics of the data. Table 2 includes price and all of the independent variables that are included and reported in the analysis that follows. Table 3 includes wine variety, wine region, and wine vintage. These variables are included in the regressions, but, because they are not the focus of the analysis, they are

Table 1 Maximum Allowed Sulfite Concentrations (mg/L) for Various Eco-Labels and Non-Eco-Labeled European and American Wine

\begin{tabular}{|c|c|c|c|c|c|c|c|c|c|}
\hline & $\begin{array}{l}\text { Sugar } \\
\text { Concentration }\end{array}$ & Biodyvin $^{a}$ & Demeter $^{\mathrm{b}}$ & FNIVAB $^{C}$ & $\begin{array}{l}\text { No Eco- } \\
\text { Label, } \\
\text { Europe }\end{array}$ & $\begin{array}{l}\text { New EU } \\
\text { Organic } \\
\text { Label }^{d}\end{array}$ & $\begin{array}{l}\text { USDA } \\
\text { Made } \\
\text { with } \\
\text { Organic } \\
\text { Grapes }^{\text {e }}\end{array}$ & $\begin{array}{l}\text { USDA } \\
\text { Organic }^{f}\end{array}$ & $\begin{array}{l}\text { No Eco- } \\
\text { Label, } \\
\text { US }^{e}\end{array}$ \\
\hline \multirow[t]{2}{*}{ Red } & $\leq 5 \mathrm{~g} / \mathrm{l}$ & 80 & 110 & 100 & 150 & $100-120$ & 100 & $<10$ & 350 \\
\hline & $>5 \mathrm{~g} / \mathrm{l}$ & 105 & 140 & 150 & 210 & 170 & 100 & $<10$ & 350 \\
\hline \multirow{2}{*}{$\begin{array}{l}\text { White, } \\
\text { Rosé }\end{array}$} & $\leq 5 \mathrm{~g} / \mathrm{l}$ & 105 & 140 & 120 & 200 & $150-170$ & 100 & $<10$ & 350 \\
\hline & $>5 \mathrm{~g} / \mathrm{l}$ & 130 & 180 & 210 & 260 & 220 & 100 & $<10$ & 350 \\
\hline $\begin{array}{l}\text { Red, } \\
\text { White, } \\
\text { Rosé }\end{array}$ & $\geq 30 \mathrm{~g} / \mathrm{l}$ & 175 & 250 & 250 & $300-400$ & $270-370$ & 100 & $<10$ & 350 \\
\hline $\begin{array}{l}\text { Red, } \\
\text { White, } \\
\text { Rosé } \\
\text { Affected } \\
\text { by Rot }\end{array}$ & $\geq 30 \mathrm{~g} / 1$ & 200 & 360 & 360 & 400 & 370 & 100 & $<10$ & 350 \\
\hline $\begin{array}{l}\text { Liqueur } \\
\text { Wines, } \\
\text { Fortified } \\
\text { Wines }\end{array}$ & & 100 & & 100 & $150-200$ & $120-170$ & 100 & $<10$ & 350 \\
\hline \multirow[t]{2}{*}{ Sparkling } & $\leq 15 \mathrm{~g} / \mathrm{l}$ & 96 & 140 & 100 & $150-235$ & 155 & 100 & $<10$ & 350 \\
\hline & $>15 \mathrm{~g} / \mathrm{l}$ & 104 & 180 & 150 & $185-235$ & 205 & 100 & $<10$ & 350 \\
\hline
\end{tabular}

aSource: Biodyvin, 2009

bSource: Demeter, 2011

'Source: FNIVAB, 2011

${ }^{\mathrm{d} S o u r c e: ~ I F O A M, ~} 2013$

e'Source: USDA NOP, 2011b

fSource: ATTTB, 2014 
Table 2 Summary Statistics of Variables Included and Reported in the Regression Analysis $(N=546)$

\begin{tabular}{|c|c|c|c|c|c|}
\hline Variable Name & Description & Mean & St. Dev. & Min & Max \\
\hline Price & Price in 2011 Euros & 10.46 & 7.99 & 3.1 & 88 \\
\hline \multicolumn{6}{|l|}{ Production Variables } \\
\hline Manual Harvest & Grapes harvested manually & 0.77 & 0.42 & 0 & 1 \\
\hline Ferments Added & Additional ferments added & 0.28 & 0.45 & 0 & 1 \\
\hline Barrel Aging & Length of barrel aging (months) & 11.30 & 10.67 & 0 & 84 \\
\hline Oak Barrel & Wine aged in an oak barrel & 0.45 & 0.50 & 0 & 1 \\
\hline Sugar Added & Additional sugar added & 0.07 & 0.25 & 0 & 1 \\
\hline Filtered & Wine filtered & 0.56 & 0.50 & 0 & 1 \\
\hline Production & Production of wine (hectoliters) & 95.95 & 181.12 & 1 & 2000 \\
\hline \multicolumn{6}{|l|}{$\mathrm{SO}_{2}$ Variables } \\
\hline $\mathrm{SO}_{2}$ & $\mathrm{SO}_{2}$ added & 0.89 & 0.31 & 0 & 1 \\
\hline $\mathrm{SO}_{2} \times$ White & $\mathrm{SO}_{2}$ added and white wine & 0.28 & 0.45 & 0 & 1 \\
\hline $\mathrm{SO}_{2} \times$ Rosé & $\mathrm{SO}_{2}$ added and rosé wine & 0.09 & 0.28 & 0 & 1 \\
\hline $\mathrm{SO} 2 \times \mathrm{Red}$ & $\mathrm{SO}_{2}$ added and red wine & 0.52 & 0.50 & 0 & 1 \\
\hline SO2 $\times$ Intended Cellar & $\mathrm{SO}_{2}$ added interacted with recommended cellaring length & 5.26 & 4.94 & 0 & 24 \\
\hline SO2 $\times$ FNIVAB & $\mathrm{SO}_{2}$ added and certified by FNIVAB & 0.27 & 0.45 & 0 & 1 \\
\hline SO2 x Biodyvin & $\mathrm{SO}_{2}$ added and certified by Biodyvin & 0.07 & 0.25 & 0 & 1 \\
\hline SO2 x Demeter & $\mathrm{SO}_{2}$ added and certified by Demeter & 0.08 & 0.28 & 0 & 1 \\
\hline \multicolumn{6}{|l|}{ Wine Characteristics } \\
\hline Intended Cellar & Recommended length of time to cellar wine (years) & 5.91 & 5.1 & 0 & 24 \\
\hline Aged & Years aged at time of wine's web entry & 2.58 & 1.74 & 1 & 14 \\
\hline$\%$ Alcohol & Percent alcohol & 12.98 & 1.18 & 5 & 18 \\
\hline Sparkling & Wine is a sparkling wine & 0.06 & 0.24 & 0 & 1 \\
\hline \multicolumn{6}{|c|}{ Wine Quality Designations and Honors } \\
\hline Hachette & Listed in the Hachette Guide to French Wine & 0.05 & 0.21 & 0 & 1 \\
\hline Hachette $\times$ Stars & $\begin{array}{l}\text { Number of stars received (if any) in the Hachette } \\
\text { Guide ( } 1-3 \text { possible) }\end{array}$ & 0.01 & 0.15 & 0 & 2 \\
\hline HachetteCDC & Coup de Coeur honor in Hachette Guide & $<0.01$ & 0.06 & 0 & 1 \\
\hline $\mathrm{AOC}$ & Appellation d'Origine Controlee Certification & 0.68 & 0.47 & 0 & 1 \\
\hline Grand Cru & Grand Cru designation & 0.03 & 0.18 & 0 & 1 \\
\hline Villages & Villages designation & 0.05 & 0.23 & 0 & 1 \\
\hline $\begin{array}{l}\text { Parker Dummy } \\
\text { Variable }\end{array}$ & Wine has a rating on eRobertparker.com & 0.24 & 0.42 & 0 & 1 \\
\hline Parker & Wine Rating on eRobertparker.com (imputed if missing) & 87.54 & 0.66 & 86 & 91 \\
\hline \multicolumn{6}{|l|}{ Winery Characteristics } \\
\hline FNIVAB & Certified organic by FNIVAB & 0.31 & 0.46 & 0 & 1 \\
\hline Biodyvin & Certified by Biodyvin & 0.07 & 0.26 & 0 & 1 \\
\hline Demeter & Certified by Demeter & 0.09 & 0.29 & 0 & 1 \\
\hline Organic Experience & Years winery has produced organically & 11.93 & 16.88 & 0 & 317 \\
\hline Total Surface Area & Total surface area of winery's production (hectares) & 20.34 & 25.25 & 2 & 200 \\
\hline
\end{tabular}


Table 3 Summary Statistics of Variables Included but Not Reported in the Regression Analysis $(N=546)$

\begin{tabular}{|c|c|c|c|c|}
\hline Variable Name & Mean & St. Dev. & Min & Max \\
\hline \multicolumn{5}{|c|}{ Wine Variety (At least $50 \%$ of wine comprised of variety) } \\
\hline Cabernet Franc & 0.04 & 0.20 & 0 & 1 \\
\hline Cabernet Sauvignon & 0.02 & 0.15 & 0 & 1 \\
\hline Carignan & 0.02 & 0.15 & 0 & 1 \\
\hline Gamay & 0.03 & 0.17 & 0 & 1 \\
\hline Grenache & 0.08 & 0.27 & 0 & 1 \\
\hline Merlot & 0.07 & 0.25 & 0 & 1 \\
\hline Pinot Noir & 0.04 & 0.21 & 0 & 1 \\
\hline Syrah & 0.04 & 0.19 & 0 & 1 \\
\hline Red other & 0.28 & 0.45 & 0 & 1 \\
\hline Chardonnay & 0.06 & 0.24 & 0 & 1 \\
\hline Chenin Blanc & 0.05 & 0.22 & 0 & 1 \\
\hline White other & 0.20 & 0.40 & 0 & 1 \\
\hline Rosé other & 0.06 & 0.24 & 0 & 1 \\
\hline \multicolumn{5}{|l|}{ Wine Region } \\
\hline Alsace/Est & 0.06 & 0.24 & 0 & 1 \\
\hline Beaujolais/Lyonnais & 0.03 & 0.18 & 0 & 1 \\
\hline Bourgogne & 0.05 & 0.21 & 0 & 1 \\
\hline Bordeaux & 0.09 & 0.29 & 0 & 1 \\
\hline Champagne & 0.02 & 0.14 & 0 & 1 \\
\hline Jura/Savoie & 0.02 & 0.15 & 0 & 1 \\
\hline Languedoc Roussillon & 0.31 & 0.46 & 0 & 1 \\
\hline Poitou/Charentes & $<0.01$ & 0.06 & 0 & 1 \\
\hline Provence/Sud-Est & 0.12 & 0.32 & 0 & 1 \\
\hline Sud-Ouest & 0.03 & 0.18 & 0 & 1 \\
\hline Val de Loire/Centre & 0.15 & 0.36 & 0 & 1 \\
\hline Vallee du Rhône & 0.11 & 0.31 & 0 & 1 \\
\hline \multicolumn{5}{|l|}{ Wine Vintage } \\
\hline 1996 & $<0.01$ & 0.06 & 0 & 1 \\
\hline 1998 & 0.01 & 0.09 & 0 & 1 \\
\hline 1999 & $<0.01$ & 0.06 & 0 & 1 \\
\hline 2000 & 0.01 & 0.10 & 0 & 1 \\
\hline 2001 & 0.01 & 0.12 & 0 & 1 \\
\hline 2002 & 0.01 & 0.12 & 0 & 1 \\
\hline 2003 & 0.05 & 0.22 & 0 & 1 \\
\hline 2004 & 0.14 & 0.35 & 0 & 1 \\
\hline 2005 & 0.21 & 0.41 & 0 & 1 \\
\hline 2006 & 0.07 & 0.25 & 0 & 1 \\
\hline 2007 & 0.10 & 0.30 & 0 & 1 \\
\hline 2008 & 0.14 & 0.34 & 0 & 1 \\
\hline 2009 & 0.14 & 0.35 & 0 & 1 \\
\hline 2010 & 0.09 & 0.29 & 0 & 1 \\
\hline
\end{tabular}


excluded from the tables for length considerations. The dataset contains 336 red wines, 178 white wines, and 59 rosé wines. The wines were produced in 12 different regions of France and represent vintages from 1996 to 2010. The average price was $€ 10.46$. Sulfur dioxide was added to $89 \%$ of the wines.

The price variable was constructed from retail prices reported by individual wineries. While these are the wineries' suggested retail prices and the price of wines sold at the winery, the actual bottles may sell to some consumers for less if the retailer discounts the wine or for more if they are sold at bars or restaurants. While this analysis would ideally include the median or average price paid by consumers, the winery's retail price is an adequate approximation since that is indeed the price paid by some consumers. Prices were reported between 2006 and 2012. Using inflation rates reported by the European Commission's Eurostat (http:// http://epp.eurostat.ec.europa.eu), prices were converted to 2011 Euros. For price and those independent variables that exhibit rightskewedness, a natural log transformation was used.

The analysis includes production variables that yield indirectly observable characteristics of the wine, directly observable wine characteristics, measures of wine quality, and winery characteristics. This last group will be absorbed by the fixed effects model, but will be reported for the OLS and random effects estimates.

The production variables include manual grape harvest, length of barrel aging, the use of additional fermenting agents, the addition of sugar, filtering, the use of an oak barrel for aging, and the total volume of production of the specific wine.

The directly observable wine characteristics include the percent alcohol; whether or not the wine is sparkling; the recommended cellaring time (observable on the website although likely not actually listed on the bottle but communicated to the consumer at the winery); the wine variety, region, and vintage; and the total amount of time the wine has already been aged. The last variable is constructed using the wine's vintage and the date at which the wine's price was entered on the website.

Since many consumers purchase wines that they have not previously tasted, they may rely on indicators of quality to help formulate their valuation of the wine. Additionally, they may experience an added utility from knowing that they are drinking a wine that has been rated highly. In France, the Hachette Guide to French Wine is a commonly used guide. Wines are entered either without any stars, indicating a wine that is typical of its region, but noteworthy, or entered with one to three stars, indicating a good, remarkable, or exceptional wine, respectively. The highest possible honor is to be listed and given the "Coup de Coeur". The 2011 guide contains 10,069 wines, and of these, only 471 received this honor (Bachelot 2010). The analysis includes indicator variables that equal one for those wines included in the guide. Additionally, the models include an interaction term between the indicator variable and the number of stars received, if any, and include an indicator variable that equals one if the wine received the Coup de Coeur.

In addition to Hachette Guide references, the models include ratings from eRobertParker.com. Very few of the specific wines in the dataset can be found in the ratings database but $24 \%$ of the wines are from wineries that have at least one of their wines represented. A Parker ratings variable was constructed using the median rating for the winery if available and using the sample median for those wineries with no ratings. The models also include indicator variables for ratings at the winery level because the 
existence of a rating may indicate higher quality than those wineries without any ratings. In one of the robustness checks of the analysis, the model is estimated separately for those wineries with a Robert Parker Rating, and those without to determine if the lack of ratings for some wineries biases results. Finally, in addition to the Hachette Guide and Parker variables, the models include indicator variables for wines that have a Grand Cru or Villages designation and wines that have Appellation d'Origine Contrôlée $(\mathrm{AOC})$ certifications.

Winery characteristics include how long the winery has been producing organically, whether or not the winery is certified by FNIVAB, Biodyvin, and/or Demeter, and the total size of the winery's production.

Finally, the models include variables pertaining to the use of $\mathrm{SO}_{2}$. The model contains an indicator variable for the addition of $\mathrm{SO}_{2}$, and this variable is interacted with indicator variables for white and rosé wines to allow the effect of added $\mathrm{SO}_{2}$ to differ for white and rosé wines, relative to red wines. Oxidative browning is more often a problem for white and rosé wines than for red wines (Waterhouse 2002). Additionally, the models contain an interaction between the $\mathrm{SO}_{2}$ variable and each of three indicator variables for whether or not the winery is certified by one of three certifying agencies: FNIVAB, Demeter, or Biodyvin. These terms allow the effect of added $\mathrm{SO}_{2}$ to vary across the different certifiers. FNIVAB is a French organization that certifies that the wine is organic while Demeter and Biodyvin are international agencies that certify that the wines are biodynamic. For all three agencies, wineries must meet specific standards in order to place the agency's label on the bottle. The base group will be those wines that claim to be organic but are not labeled by one of these three organizations. Some wines in this group may have an Ecocert or a Nature et Progrès organic certification; data on wineries participating in these programs were not available to identify them in the dataset. If consumers are concerned about the level of added $\mathrm{SO}_{2}$ in their wine, ecolabels may add value to the wine because it assures the consumer that the wine's sulfite content meets the certifying agency's limits (Table 1).

Each wine in the database includes the recommended drinking period. To construct a variable for intended cellaring time, the year in which the wine was listed in the database was subtracted from the final year in the drinking period. The log of this variable was also interacted with the $\mathrm{SO}_{2}$ variable. Since $\mathrm{SO}_{2}$ is a preservative, its addition is hypothesized to add more value to those wines that will be cellared for a longer period.

\section{Results and Discussion}

\section{All wines}

Table 4 reports estimation results when all observations are utilized together. Five of the $\mathrm{SO}_{2}$ variables are statistically significant. First, the effect of an addition of $\mathrm{SO}_{2}$ on the base group of wines (red wines not certified by FNIVAB, Biodyvin, or Demeter that are intended to be consumed shortly after purchase) is negative, with a marginal effect of a $23 \%$ reduction in price. For wines certified by Biodyvin, the addition of $\mathrm{SO}_{2}$ leads to an additional $30 \%$ reduction in price on top of the base effect. Analysis of French consumers' perceptions of biodynamic, organic, and no sulfites added wine reveals two perceptions that likely influence this result. First consumers associate organic and biodynamic wine with wines that are good for their health, while they also associate no sulfites added wines as being good for their health (Remaud and Sirieix 2012). 
Table 4 Effects of Added $\mathrm{SO}_{2}$, Production Variables, Wine Characteristics, Indicators of Quality, and Winery Characteristics on Wine Price

\begin{tabular}{|c|c|c|}
\hline Ln(Price) & Coeff. & St. Error \\
\hline \multicolumn{3}{|l|}{$\mathrm{SO}_{2}$ Variables } \\
\hline $\mathrm{SO}_{2}$ & $-0.226^{b}$ & $(0.099)$ \\
\hline $\mathrm{SO}_{2} \times$ White & $0.252^{\mathrm{a}}$ & $(0.151)$ \\
\hline $\mathrm{SO}_{2} \times$ Rosé & $0.482^{b}$ & $(0.177)$ \\
\hline $\mathrm{SO}_{2} \times \mathrm{FNIVAB}$ & -0.045 & $(0.100)$ \\
\hline $\mathrm{SO}_{2} \times$ Biodyvin & $-0.300^{b}$ & $(0.133)$ \\
\hline $\mathrm{SO}_{2} \times$ Demeter & 0.021 & $(0.099)$ \\
\hline $\mathrm{SO}_{2} \times \mathrm{Ln}($ Intended Cellar) & $0.148^{b}$ & $(0.046)$ \\
\hline \multicolumn{3}{|l|}{ Production Variables } \\
\hline Ln(Intended Cellar) & $0.098^{b}$ & $(0.041)$ \\
\hline Manual Harvest & $0.185^{b}$ & $(0.055)$ \\
\hline Ferments Added & 0.047 & $(0.053)$ \\
\hline Sugar Added & -0.180 & $(0.123)$ \\
\hline Filtered & 0.031 & $(0.057)$ \\
\hline Oak Barrel & $0.157^{c}$ & $(0.026)$ \\
\hline Ln(Production) & $-0.117^{c}$ & $(0.023)$ \\
\hline \multicolumn{3}{|l|}{ Wine Characteristics } \\
\hline Ln(Aged) & 0.104 & $(0.085)$ \\
\hline$\%$ Alcohol & $0.027^{\mathrm{a}}$ & $(0.015)$ \\
\hline Sparkling & $0.303^{c}$ & $(0.071)$ \\
\hline White & -0.237 & $(0.216)$ \\
\hline Rosé & $-0.470^{b}$ & $(0.205)$ \\
\hline \multicolumn{3}{|l|}{ Indicators of Quality } \\
\hline Hachette & -0.054 & $(0.056)$ \\
\hline Hachette $\times$ Stars & $-0.083^{\mathrm{a}}$ & $(0.049)$ \\
\hline Hachette CDC & 0.053 & $(0.074)$ \\
\hline $\mathrm{AOC}$ & $0.203^{b}$ & $(0.062)$ \\
\hline Grand Cru & -0.043 & $(0.146)$ \\
\hline Villages & -0.013 & $(0.088)$ \\
\hline \multicolumn{3}{|l|}{ Parker Dummy Variable } \\
\hline Parker Rating & -0.038 & $(0.111)$ \\
\hline \multicolumn{3}{|l|}{ Winery Characteristics } \\
\hline \multicolumn{3}{|l|}{ FNIVAB } \\
\hline \multicolumn{3}{|l|}{ Biodyvin } \\
\hline \multicolumn{3}{|l|}{ Demeter } \\
\hline Ln(OrgExp) & 0.091 & $(0.168)$ \\
\hline \multicolumn{3}{|l|}{ Ln(Total Area) } \\
\hline Controls for Variety, Region, Vintage & Yes & \\
\hline Constant & 4.750 & $(9.631)$ \\
\hline N & 542 & \\
\hline
\end{tabular}


Table 4 Effects of Added $\mathrm{SO}_{2}$, Production Variables, Wine Characteristics, Indicators of Quality, and Winery Characteristics on Wine Price (Continued)

\begin{tabular}{ll}
\hline$R^{2}$ & 0.587 \\
Hausman Test Chi' (52) & $73.85^{\mathrm{b}}$ \\
Model Type & Fixed Effects \\
\hline
\end{tabular}

Degrees of freedom reported in parentheses for the Hausman Test

$\mathrm{a}$, , and ${ }^{\mathrm{i}}$ indicate significance at the $10 \%, 5 \%$, and $1 \%$ level, respectively. Heteroskedastic robust standard errors reported in parentheses

Consequently, the addition of sulfites to Biodyvin wine likely negates the perceived health effects of the wine, leading to a negative effect.

For non-Biodyvin white and rosé wines, the addition of $\mathrm{SO}_{2}$ will have a net positive effect of almost $3 \%$ and $26 \%$, respectively. For Biodyvin white and rosé wines, the addition of added $\mathrm{SO}_{2}$ still yields a net negative effect. Since white and rosé wines are more likely to oxidize than red wines, the addition of $\mathrm{SO}_{2}$ appears to be beneficial or less negative for white and rosé wines than red wines. Column 1 of Table 5 lists the net effect of added $\mathrm{SO}_{2}$ on wines that are intended to be consumed immediately for the various categories of wines.

Finally, as hypothesized, the addition of $\mathrm{SO}_{2}$ has an increasingly positive effect as the length of intended cellaring time increases (Table 4). The "Pooled Regression" column of Table 6 lists the intended cellaring time length at which the effect of adding $\mathrm{SO}_{2}$ becomes positive for the various types of wines, as estimated when all data are pooled together. For those wines for which the net effect is already positive, the critical cellaring time is listed as "0.00." For those wines for which the net effect is negative for wines intended to be consumed immediately, the time listed is the time at which the positive

Table 5 The Percent Change in Price Due to Added $\mathrm{SO}_{2}$ by Wine Type for Wines Intended to be Consumed Immediately After Purchase

\begin{tabular}{|c|c|c|c|c|c|c|}
\hline & $\begin{array}{l}\text { Pooled } \\
\text { Regression }\end{array}$ & $\begin{array}{l}\text { Red or White } \\
\text { Only }\end{array}$ & $\mathrm{AOC}^{\mathrm{a}}$ & Non-AOC & Parker & Non-Parker ${ }^{b}$ \\
\hline \multicolumn{7}{|l|}{ Base } \\
\hline Red & $-22.6 \%$ & $-51.9 \%$ & $-54.4 \%$ & $-52.6 \%$ & $0.0 \%$ & $-62.3 \%$ \\
\hline Rosé & $25.6 \%$ & $\mathrm{~N} / \mathrm{A}$ & $0.0 \%$ & $27.9 \%$ & $\mathrm{~N} / \mathrm{A}$ & $25.9 \%$ \\
\hline White & $2.6 \%$ & $0.0 \%$ & $0.0 \%$ & $-52.6 \%$ & $0.0 \%$ & $-27.5 \%$ \\
\hline \multicolumn{7}{|c|}{ Biodyvin } \\
\hline Red & $-52.6 \%$ & $-82.6 \%$ & $-115.2 \%$ & \multirow{3}{*}{$\begin{array}{l}\text { Not included in } \\
\text { model }\end{array}$} & \multirow{3}{*}{$\begin{array}{l}\text { Not included in } \\
\text { model }\end{array}$} & \multirow{3}{*}{$\begin{array}{l}\text { Not included in } \\
\text { model }\end{array}$} \\
\hline Rosé & $-4.4 \%$ & $\mathrm{~N} / \mathrm{A}$ & $-63.1 \%$ & & & \\
\hline White & $-27.4 \%$ & $0.0 \%$ & $-63.1 \%$ & & & \\
\hline \multicolumn{7}{|c|}{ Demeter } \\
\hline Red & $-22.6 \%$ & $-51.9 \%$ & $2.7 \%$ & \multirow{3}{*}{$\begin{array}{l}\text { Not included in } \\
\text { model }\end{array}$} & $21.0 \%$ & $-12.5 \%$ \\
\hline Rosé & $25.6 \%$ & $\mathrm{~N} / \mathrm{A}$ & $0.0 \%$ & & N/A & $25.9 \%$ \\
\hline White & $2.6 \%$ & $0.0 \%$ & $0.0 \%$ & & $21.0 \%$ & $-27.5 \%$ \\
\hline \multicolumn{7}{|l|}{ FNIVAB } \\
\hline Red & $-22.6 \%$ & $-51.9 \%$ & $-54.4 \%$ & $-15.9 \%$ & $-57.6 \%$ & $-62.3 \%$ \\
\hline Rosé & $25.6 \%$ & $\mathrm{~N} / \mathrm{A}$ & $0.0 \%$ & $64.6 \%$ & $\mathrm{~N} / \mathrm{A}$ & $25.9 \%$ \\
\hline White & $2.6 \%$ & $0.0 \%$ & $0.0 \%$ & $-15.9 \%$ & $-57.6 \%$ & $-27.5 \%$ \\
\hline
\end{tabular}

${ }^{\mathrm{a}}$ Estimates for red wines come from regression using only red $\mathrm{AOC}$ wines

${ }^{b}$ Estimates for red wines come from regression using only red Non-Parker wines 
Table 6 Intended Cellaring Time at which the Effect of Added $\mathrm{SO}_{2}$ is Positive (Years)

\begin{tabular}{|c|c|c|c|c|c|c|}
\hline & $\begin{array}{l}\text { Pooled } \\
\text { Regression }\end{array}$ & $\begin{array}{l}\text { Red or White } \\
\text { Only }\end{array}$ & $\mathrm{AOC}^{\mathrm{a}}$ & Non-AOC & Parker & Non-Parker ${ }^{\mathrm{b}}$ \\
\hline \multicolumn{7}{|l|}{ Base } \\
\hline Red & 4.60 & 5.48 & 4.40 & 13.69 & 0.00 & 6.96 \\
\hline Rosé & 0.00 & N/A & 0.00 & 0.00 & N/A & 0.00 \\
\hline White & 0.00 & 0.00 & 0.00 & 13.69 & 0.00 & 4.61 \\
\hline \multicolumn{7}{|c|}{ Biodyvin } \\
\hline Red & 34.95 & 7.49 & 23.08 & \multirow{3}{*}{$\begin{array}{l}\text { Not included in } \\
\text { model }\end{array}$} & \multirow{3}{*}{$\begin{array}{l}\text { Not included in } \\
\text { model }\end{array}$} & \multirow{3}{*}{$\begin{array}{l}\text { Not included in } \\
\text { model }\end{array}$} \\
\hline Rosé & 1.35 & $\mathrm{~N} / \mathrm{A}$ & 884.43 & & & \\
\hline White & 6.37 & 0.00 & 884.43 & & & \\
\hline \multicolumn{7}{|c|}{ Demeter } \\
\hline Red & 4.00 & 5.48 & 8.31 & \multirow{3}{*}{$\begin{array}{l}\text { Not included in } \\
\text { model }\end{array}$} & 0.00 & 3.53 \\
\hline Rosé & 0.00 & N/A & 0.00 & & N/A & 0.00 \\
\hline White & 0.00 & 0.00 & 0.00 & & 0.00 & 4.61 \\
\hline \multicolumn{7}{|l|}{ FNIVAB } \\
\hline Red & 4.60 & 5.48 & 0.00 & 2.21 & 10.70 & 6.96 \\
\hline Rosé & 0.00 & $\mathrm{~N} / \mathrm{A}$ & 0.00 & 0.00 & 10.70 & 0.00 \\
\hline White & 0.00 & 0.00 & 0.00 & 2.21 & 10.70 & 4.61 \\
\hline
\end{tabular}

${ }^{\mathrm{a}}$ Estimates for red wines come from regression using only red $\mathrm{AOC}$ wines, and marginally insignificant coefficient on $\mathrm{SO}_{2}$ $x$ Ln(Intended Cellar) used for rosé and white wines

${ }^{\mathrm{b}}$ Estimates for red wines come from regression using only red Non-Parker wines

effect of cellaring length interacted with added $\mathrm{SO}_{2}$ just equals the net negative effect of the other $\mathrm{SO}_{2}$ variables. The length is longest for red Biodyvin wines for which it takes a cellaring time of about 35 years for the addition of $\mathrm{SO}_{2}$ to be beneficial.

Several other variables have significant coefficients with signs that are as hypothesized (Table 4). Wines with larger production and rosé wines are associated with a decrease in price. Manual harvest, the use of an oak barrel for aging, an AOC certification, sparkling wines, and increasing alcohol content are all associated with an increase in price. These results are consistent with expectations.

\section{Red vs. White wines}

When the sample is split into white and red wines, the first thing to note is that many variables lose significance (Table 7). The smaller sample size, particularly for white wines, likely causes this result. However, even with the smaller sample size and fewer significant coefficients, three of the $\mathrm{SO}_{2}$ variables remain significant in the regression for red wines and one in the regression for white wines. The addition of $\mathrm{SO}_{2}$ reduces price by $52 \%$ for the base group of red wines, and by an additional $31 \%$ for red wines that are certified by Biodyvin. The interaction between Biodyvin and added $\mathrm{SO}_{2}$ is dropped for white wines due to a lack of variation in the addition of $\mathrm{SO}_{2}$ for Biodyvin white wines. As seen in the pooled regression, the interaction between the addition of $\mathrm{SO}_{2}$ and the intended cellaring time is statistically significant and positive for both red and white wines. For white wines, the base effect of added $\mathrm{SO}_{2}$ is neutral, and the net effect is positive and increasing as intended cellaring length increases. For nonBiodyvin red wines, the net effect becomes positive for wines that are expected to be aged for at least 5.5 years (Table 6). For Biodyvin red wines, the net effect becomes 
Table 7 Effects of Added $\mathrm{SO}_{2}$, Production Variables, Wine Characteristics, Indicators of Quality, and Winery Characteristics on Wine Price for White and Red Wines

\begin{tabular}{|c|c|c|c|c|}
\hline \multirow[t]{2}{*}{ Ln(Price) } & \multicolumn{2}{|l|}{ White } & \multicolumn{2}{|l|}{ Red } \\
\hline & Coefficient & Stnd. Error & Coefficient & Stnd. Error \\
\hline \multicolumn{5}{|l|}{$\mathrm{SO}_{2}$ Variables } \\
\hline $\mathrm{SO}_{2}$ & -0.025 & $(0.197)$ & $-0.519^{c}$ & $(0.157)$ \\
\hline $\mathrm{SO}_{2} \times \mathrm{FNIVAB}$ & -0.418 & $(0.406)$ & -0.067 & $(0.142)$ \\
\hline $\mathrm{SO}_{2} \times$ Biodyvin & & & $-0.307^{a}$ & $(0.173)$ \\
\hline $\mathrm{SO}_{2} \times$ Demeter & -0.168 & $(0.252)$ & 0.277 & $(0.198)$ \\
\hline $\mathrm{SO}_{2} \times \operatorname{Ln}($ Intended Cellar) & $0.221^{b}$ & $(0.106)$ & $0.305^{c}$ & $(0.083)$ \\
\hline \multicolumn{5}{|l|}{ Production Variables } \\
\hline Ln(Intended Cellar) & -0.001 & $(0.086)$ & -0.102 & $(0.072)$ \\
\hline Manual Harvest & $0.248^{\mathrm{a}}$ & $(0.131)$ & $0.176^{\mathrm{b}}$ & $(0.063)$ \\
\hline Ferments Added & -0.033 & $(0.076)$ & 0.027 & $(0.064)$ \\
\hline Sugar Added & -0.185 & $(0.238)$ & 0.157 & $(0.117)$ \\
\hline Filtered & -0.108 & $(0.144)$ & $-0.115^{b}$ & $(0.059)$ \\
\hline Oak Barrel & $0.238^{c}$ & $(0.059)$ & $0.190^{c}$ & $(0.037)$ \\
\hline Ln(Production) & $-0.148^{b}$ & $(0.047)$ & $-0.050^{\mathrm{a}}$ & $(0.029)$ \\
\hline \multicolumn{5}{|l|}{ Wine Characteristics } \\
\hline Ln(Aged) & 0.127 & $(0.093)$ & $0.128^{b}$ & $(0.065)$ \\
\hline$\%$ Alcohol & 0.008 & $(0.022)$ & $0.064^{b}$ & $(0.022)$ \\
\hline Sparkling & $0.388^{b}$ & $(0.156)$ & $0.364^{b}$ & $(0.155)$ \\
\hline \multicolumn{5}{|l|}{ Indicators of Quality } \\
\hline Hachette & -0.105 & $(0.119)$ & -0.044 & $(0.066)$ \\
\hline Hachette $\times$ Stars & -0.215 & $(0.212)$ & -0.049 & $(0.066)$ \\
\hline Hachette CDC & $0.207^{*}$ & $(0.107)$ & 0.051 & $(0.095)$ \\
\hline $\mathrm{AOC}$ & 0.152 & $(0.121)$ & $0.150^{\mathrm{b}}$ & $(0.066)$ \\
\hline Grand Cru & -0.153 & $(0.192)$ & 0.393 & $(0.288)$ \\
\hline Villages & $0.433^{c}$ & $(0.126)$ & -0.082 & $(0.105)$ \\
\hline Parker Dummy Variable & $0.185^{b}$ & $(0.087)$ & 0.079 & $(0.079)$ \\
\hline Parker Rating & -0.028 & $(0.074)$ & -0.010 & $(0.037)$ \\
\hline \multicolumn{5}{|l|}{ Winery Characteristics } \\
\hline FNIVAB & 0.411 & $(0.386)$ & 0.182 & $(0.160)$ \\
\hline Biodyvin & -0.028 & $(0.150)$ & $0.556^{\mathrm{b}}$ & $(0.179)$ \\
\hline Demeter & 0.177 & $(0.347)$ & $-0.361^{a}$ & $(0.197)$ \\
\hline $\operatorname{Ln}($ OrgExp) & $-0.099^{a}$ & $(0.053)$ & -0.046 & $(0.041)$ \\
\hline Ln(Total Area) & $0.139^{a}$ & $(0.076)$ & 0.009 & $(0.038)$ \\
\hline Controls for Variety, Region, Vintage & Yes & & Yes & \\
\hline Constant & 4.081 & $(6.536)$ & 2.249 & (3.338) \\
\hline$N$ & 169 & & 321 & \\
\hline$R^{2}$ & 0.745 & & 0.641 & \\
\hline Hausman Test Chi²(45),(54) & 39.18 & & 45.53 & \\
\hline Model Type & Random Eff & & Random Ef & \\
\hline
\end{tabular}

${ }^{\mathrm{a}},{ }_{\text {, and }}{ }^{\mathrm{i}}$ indicate significance at the $10 \%, 5 \%$, and $1 \%$ level, respectively. Heteroskedastic robust standard errors reported in parentheses. Degrees of freedom for each regression are reported in parentheses for the Hausman Tests 
positive for wines that are expected to be cellared for at least 7.5 years. The longer cellaring length is due to the base negative effect of added $\mathrm{SO}_{2}$ combined with the negative effect of the interaction between $\mathrm{SO}_{2}$ and Biodyvin. The effect of added $\mathrm{SO}_{2}$ on Biodyvin red wines is likely driven by consumer preferences. As discussed earlier, those consumers who prefer to drink biodynamic wines may be more health conscious and also associate sulfites with health effects. Consequently they are not willing to pay as much for certified wines that contain added $\mathrm{SO}_{2}$. The differing effects for white and red wines are likely driven by the differences in their tendencies to oxidize, as discussed earlier.

For both red and white wines, increasing production of the wine decreases its price, indicating quality and quantity tradeoffs in wine production. The effect of manual harvest, oak barrels, and sparkling wine remain qualitatively the same in the regressions for red and white compared to the pooled sample. The AOC certification has a positive effect on the price of red wines, increasing price by about $15 \%$, but has no statistically significant effect on white wines. Conversely, the Hachette Coup de Coeur and the existence of a Parker rating at the winery level have positive effects of about $21 \%$ and $19 \%$, respectively, on white wines, but no statistically significant effect on red wines.

It is interesting to note that while the existence of a Parker rating at the winery level is statistically significant, the rating itself is not a significant determinant of price. A meta-analysis of the relationship between wine prices and quality ratings demonstrates that the literature finds a wide range of correlations between price and ratings ranging from negative correlation to a large positive correlation approaching a correlation coefficient of one (Oczkowski and Doucouliagos 2014). Where any given sample falls on this continuum is likely a result of the kinds of consumers purchasing the wines consumed in the sample. Consumers who have a stronger knowledge of wine ratings and what they mean will pay more for wines with higher ratings, while those without strong knowledge of what the ratings mean may see the existence of any rating as an indicator of quality without distinguishing between wines with higher or lower ratings. Additionally, expert ratings do not necessary align with the average consumer's ratings, which would explain a lack of correlation between quality ratings and price (Schiefer and Fischer 2008).

The ecolabels appear to affect red wines, with Biodyvin having a positive effect and Demeter having a negative effect on price, while the coefficients on these variables are insignificant in the regression for white wines. The significant effect of a Biodyvin label paired with the insignificant effect of FNIVAB (organic) and negative effect of Demeter (biodynamic) labels may be a result of the unique requirements of the Biodyvin certification process. As part of the process, wineries must have their wine tasted. While the certification agency claims that this tasting is not to determine or guarantee quality, it may be perceived as a guarantee of quality (Biodyvin 2012). In fact, the website morethanorganic.com states, "Wines carrying their Biodyvin logo must be made from biodynamic grapes and are certified by ECOCERT. The mark is also a guarantee of quality: all Biodyvin wines are tasted and approved by SIVCBD" (Morethanorganic 2015). ${ }^{7}$ The other eco-certification processes do not include tasting the wine. The negative coefficient on Demeter certification may be due to its widespread use. Unlike Biodyvin and FNIVAB, Demeter is not a wine-specific label. 
Its association with more commonplace products like cereal and bread may lessen its value when attached to wine, explaining its negative coefficient.

\section{Probability of added $\mathrm{SO}_{2}$}

One could argue that the coefficients on the $\mathrm{SO}_{2}$ variables could be biased. Winemakers may add $\mathrm{SO}_{2}$ to wines that are of higher quality and will receive a higher price or conversely, they may add $\mathrm{SO}_{2}$ to wines that are of lower quality if lower quality wines are more likely to spoil. If that is the case, the effect attributed to $\mathrm{SO}_{2}$ will include this quality effect, thus over- or underestimating the true effect of $\mathrm{SO}_{2}$. While there are several controls for quality, none are perfect controls. Table 8 shows the

Table 8 Determinants of Added $\mathrm{SO}_{2}$

\begin{tabular}{|c|c|c|c|c|}
\hline & Coefficient & Stnd. Error & Marginal Effect & Stnd. Error \\
\hline \multicolumn{5}{|l|}{ Production Variables } \\
\hline Ln(Intended Cellar) & -0.080 & $(0.283)$ & -0.001 & $(0.004)$ \\
\hline Ferments Added & $3.439^{b}$ & $(1.680)$ & $0.037^{\mathrm{a}}$ & $(0.022)$ \\
\hline Sugar Added & 1.046 & $(1.299)$ & 0.010 & $(0.010)$ \\
\hline Filtered & $2.451^{b}$ & $(0.799)$ & 0.049 & $(0.035)$ \\
\hline Oak Barrel & 0.130 & $(0.686)$ & 0.002 & $(0.010)$ \\
\hline Ln(Barrel Aging) & $0.682^{b}$ & $(0.269)$ & $0.010^{\mathrm{b}}$ & $(0.005)$ \\
\hline \multicolumn{5}{|l|}{ Wine Characteristics } \\
\hline Ln(Price) & -0.056 & $(0.525)$ & -0.001 & $(0.008)$ \\
\hline Ln(Price) $\times$ White & 1.018 & $(0.964)$ & 0.015 & $(0.016)$ \\
\hline Ln(Price) x Rosé & $1.112^{\mathrm{a}}$ & $(0.629)$ & 0.016 & $(0.012)$ \\
\hline$\%$ Alcohol & -0.162 & $(0.178)$ & -0.002 & $(0.003)$ \\
\hline Sparkling & $-2.445^{b}$ & $(0.950)$ & -0.124 & $(0.127)$ \\
\hline \multicolumn{5}{|l|}{ Indicators of Quality } \\
\hline $\mathrm{AOC}$ & 0.272 & $(0.481)$ & 0.004 & $(0.008)$ \\
\hline Grand Cru & -0.323 & $(1.795)$ & -0.005 & $(0.034)$ \\
\hline Villages & $1.709^{\mathrm{a}}$ & $(0.927)$ & 0.014 & $(0.010)$ \\
\hline Parker Dummy Variable & $-2.410^{b}$ & $(0.861)$ & -0.079 & $(0.051)$ \\
\hline Parker Rating & $1.105^{\mathrm{b}}$ & $(0.543)$ & 0.016 & $(0.011)$ \\
\hline \multicolumn{5}{|l|}{ Winery Characteristics } \\
\hline FNIVAB & $-1.015^{*}$ & $(0.572)$ & -0.019 & $(0.018)$ \\
\hline Biodyvin & 2.845 & (3.278) & 0.017 & $(0.012)$ \\
\hline Demeter & 0.950 & $(0.802)$ & 0.010 & $(0.008)$ \\
\hline $\operatorname{Ln}($ OrgExp) & $-0.872^{\mathrm{b}}$ & $(0.343)$ & $-0.013^{\mathrm{a}}$ & $(0.007)$ \\
\hline Ln(Total Area) & $1.736^{\mathrm{b}}$ & $(0.545)$ & $0.025^{b}$ & $(0.011)$ \\
\hline Controls for Variety, Region, Vintage & Yes & & & \\
\hline Constant & $-98.352^{b}$ & $(47.549)$ & & \\
\hline $\mathrm{N}$ & 407 & & & \\
\hline$R^{2}$ & 0.497 & & & \\
\hline Model Type & Probit & & & \\
\hline
\end{tabular}

Marginal effect denotes the percent in the probability of added $\mathrm{SO}_{2}$ resulting from a one-unit change in the explanatory variable

Heteroskedastic robust standard errors reported in parentheses

a , band ${ }^{c}$ indicate significance at the $10 \%, 5 \%$, and $1 \%$ level, respectively 
results of a probit model predicting the probability that a wine contains added $\mathrm{SO}_{2}$. Wines with added ferments, that have been filtered, that are made by larger wineries, and that have longer barrel aging lengths are more likely to contain added $\mathrm{SO}_{2}$ than their counterparts. Sparkling wines, FNIVAB wines, and wines made by wineries with more organic experience are less likely to have added $\mathrm{SO}_{2}$. Interestingly, the existence of a Parker rating at the winery level decreases the probability that the wine contains added $\mathrm{SO}_{2}$, but higher ratings increase the probability that the wine contains added $\mathrm{SO}_{2}$. The Parker dummy variable has a positive coefficient in the price models, while the rating itself is insignificant. If the existence of a Parker rating is a better indicator of the consumer's perception of quality than the rating itself, then higher quality wines appear less likely to contain added $\mathrm{SO}_{2}$, while wines that critics rate highly are more likely to contain added $\mathrm{SO}_{2}$.

Of the three price variables included in the probit model, only the interaction between price and the rosé indicator variable is significant. Higher priced rosé wines are more likely to contain added $\mathrm{SO}_{2}$ than lower priced rosé wines. This relationship may bias results in the regression model using the pooled sample. However, when the sample is split between red and white wines, no rosé wines are included, eliminating any possible bias from the relationship found here. The insignificance of price and price interacted with white wines suggests that $\mathrm{SO}_{2}$ is not more likely to be added to wines of higher or lower price.

\section{High vs. Low quality wine}

To address possible bias arising from an imperfect measure of quality, the sample was split by measures of quality. First, it is split based on whether or not the wine has an AOC certification. The first split includes both red and white wines in both the AOC and non-AOC groups. Then the model is estimated for only red $\mathrm{AOC}$ wines. The other possible groups (white AOC, white non-AOC, and red non-AOC) do not contain enough observations to estimate the full model.

Table 9 presents the estimates for these models. The effect of added $\mathrm{SO}_{2}$ remains negative for the base group of red wines in the regression containing all non-AOC wines and the regression containing only red AOC wines, and the magnitude is similar across the groupings. For Biodyvin wines in the regressions containing all AOC wines and only red $\mathrm{AOC}$ wines, the addition of $\mathrm{SO}_{2}$ has an additional negative effect on price. There are only 13 non-AOC Biodyvin wines and all of them contain added $\mathrm{SO}_{2}$, which does not allow the effect of the interaction term to be estimated for the non-AOC group. The robustness of the effect of added $\mathrm{SO}_{2}$ on red wines and on Biodyvin wines within smaller groups of similar quality suggests that these results are not just picking up correlation caused by an omitted variable.

For the regression containing only red $\mathrm{AOC}$ wines, the addition of $\mathrm{SO}_{2}$ for Demeter wines has a positive effect on price that just outweighs the negative base effect of added $\mathrm{SO}_{2}$. Consumers of Demeter and Biodyvin wines likely differ in their valuation of added $\mathrm{SO}_{2}$. Lastly, the interaction between added $\mathrm{SO}_{2}$ and intended cellaring length is statistically significant and positive in the regressions containing all non-AOC wines and only red AOC wines. ${ }^{8}$ The AOC and Non-AOC columns of Table 6 show the intended cellaring lengths at which the effect of added $\mathrm{SO}_{2}$ becomes positive. Notably, the cellaring 
Table 9 Effects of Added $\mathrm{SO}_{2}$, Production Variables, Wine Characteristics, Indicators of Quality, and Winery Characteristics on Prices for AOC, Non-AOC, and Red AOC Wines

\begin{tabular}{|c|c|c|c|c|c|c|}
\hline & \multicolumn{2}{|l|}{$\mathrm{AOC}$} & \multicolumn{2}{|c|}{ Non-AOC } & \multicolumn{2}{|l|}{ Red AOC } \\
\hline & Coeff. & St. Error & Coeff. & St. Error & Coeff. & St. Error \\
\hline \multicolumn{7}{|l|}{$\mathrm{SO}_{2}$ Variables } \\
\hline $\mathrm{SO}_{2}$ & -0.188 & $(0.168)$ & $-0.526^{b}$ & $(0.260)$ & $-0.544^{b}$ & $(0.234)$ \\
\hline $\mathrm{SO}_{2} \times$ White & 0.087 & $(0.132)$ & 0.712 & $(0.427)$ & & \\
\hline $\mathrm{SO}_{2} \times$ Rosé & 0.246 & $(0.186)$ & $0.805^{b}$ & $(0.256)$ & & \\
\hline $\mathrm{SO}_{2} \times \mathrm{FNIVAB}$ & 0.302 & $(0.231)$ & $0.367^{\mathrm{a}}$ & $(0.206)$ & 0.107 & $(0.285)$ \\
\hline $\mathrm{SO}_{2} \times$ Biodyvin & $-0.631^{b}$ & (0.199) & & & $-0.608^{b}$ & $(0.287)$ \\
\hline $\mathrm{SO}_{2} \times$ Demeter & 0.244 & $(0.174)$ & & & $0.571^{a}$ & $(0.344)$ \\
\hline $\mathrm{SO}_{2} \times \mathrm{Ln}$ (Intended Cellar) & 0.093 & $(0.060)$ & $0.201^{\mathrm{a}}$ & $(0.101)$ & $0.367^{c}$ & $(0.105)$ \\
\hline \multicolumn{7}{|l|}{ Production Variables } \\
\hline Ln(Intended Cellar) & 0.080 & $(0.053)$ & 0.114 & $(0.076)$ & $-0.206^{b}$ & $(0.089)$ \\
\hline Manual Harvest & $0.215^{b}$ & $(0.080)$ & $0.205^{b}$ & $(0.097)$ & 0.149 & $(0.093)$ \\
\hline Ferments Added & -0.033 & $(0.077)$ & 0.046 & $(0.070)$ & 0.066 & $(0.101)$ \\
\hline Sugar Added & $-0.212^{\mathrm{a}}$ & (0.118) & 0.482 & $(0.290)$ & 0.222 & $(0.136)$ \\
\hline Filtered & -0.007 & $(0.067)$ & 0.029 & $(0.112)$ & $-0.148^{\mathrm{a}}$ & $(0.079)$ \\
\hline Oak Barrel & $0.184^{c}$ & $(0.037)$ & $0.194^{b}$ & $(0.082)$ & $0.212^{c}$ & $(0.044)$ \\
\hline Ln(Production) & $-0.077^{\mathrm{b}}$ & $(0.028)$ & $-0.144^{c}$ & $(0.040)$ & -0.014 & $(0.041)$ \\
\hline \multicolumn{7}{|l|}{ Wine Characteristics } \\
\hline Ln(Aged) & 0.104 & $(0.065)$ & 0.253 & $(0.212)$ & 0.088 & $(0.086)$ \\
\hline$\%$ Alcohol & $0.037^{b}$ & $(0.019)$ & 0.009 & $(0.039)$ & $0.132^{b}$ & $(0.041)$ \\
\hline Sparkling & $0.173^{b}$ & $(0.081)$ & 0.034 & $(0.091)$ & 0.335 & $(0.233)$ \\
\hline White & -0.109 & $(0.190)$ & -0.640 & $(0.440)$ & & \\
\hline Rosé & -0.239 & $(0.186)$ & $-0.732^{b}$ & $(0.219)$ & & \\
\hline \multicolumn{7}{|l|}{ Indicators of Quality } \\
\hline Hachette & -0.081 & $(0.068)$ & 0.191 & $(0.153)$ & -0.044 & $(0.097)$ \\
\hline Hachette $\times$ Stars & -0.065 & $(0.064)$ & & & -0.026 & $(0.090)$ \\
\hline Hachette CDC & 0.071 & $(0.111)$ & & & -0.092 & $(0.160)$ \\
\hline Grand Cru & 0.186 & $(0.158)$ & -0.185 & $(0.378)$ & 0.446 & $(0.302)$ \\
\hline Villages & 0.019 & $(0.105)$ & 0.188 & $(0.236)$ & -0.161 & $(0.131)$ \\
\hline Parker Dummy Variable & 0.125 & $(0.083)$ & & & 0.019 & $(0.094)$ \\
\hline Parker Rating & -0.065 & $(0.041)$ & & & 0.037 & $(0.039)$ \\
\hline \multicolumn{7}{|l|}{ Winery Characteristics } \\
\hline FNIVAB & -0.158 & $(0.229)$ & & & 0.072 & $(0.300)$ \\
\hline Biodyvin & $0.823^{c}$ & $(0.211)$ & & & $0.985^{c}$ & $(0.272)$ \\
\hline Demeter & -0.180 & $(0.221)$ & & & $-0.725^{\mathrm{b}}$ & $(0.365)$ \\
\hline Ln(OrgExp) & $-0.080^{\mathrm{a}}$ & $(0.041)$ & 0.430 & $(0.369)$ & -0.039 & $(0.043)$ \\
\hline Ln(Total Area) & 0.010 & $(0.051)$ & & & -0.016 & $(0.047)$ \\
\hline Controls for Variety, Region, Vintage & Yes & & Yes & & Yes & \\
\hline Constant & $7.353^{b}$ & (3.593) & 1.032 & & -2.524 & (3.674) \\
\hline
\end{tabular}


Table 9 Effects of Added $\mathrm{SO}_{2}$, Production Variables, Wine Characteristics, Indicators of Quality, and Winery Characteristics on Prices for AOC, Non-AOC, and Red AOC Wines (Continued)

\begin{tabular}{|c|c|c|c|}
\hline $\mathrm{N}$ & 370 & 172 & 222 \\
\hline$R^{2}$ & 0.601 & 0.774 & 0.666 \\
\hline Hausman Test Chi²(63),(44),(54) & 62.89 & $52.46^{c}$ & 47.98 \\
\hline Model Type & Random Effects & Fixed Effects & Random Effects \\
\hline
\end{tabular}

a , and ${ }^{~}$ indicate significance at the $10 \%, 5 \%$, and $1 \%$ level, respectively. Heteroskedastic robust standard errors reported in parentheses. Degrees of freedom for each regression are reported in parentheses for the Hausman Tests

length at which the value of added $\mathrm{SO}_{2}$ becomes positive is relatively high for rosé and white AOC wines certified by Biodyvin. For Biodyvin wines, there is a large negative effect of added $\mathrm{SO}_{2}$ (Table 9). Additionally, the marginal effect of an extra year of cellaring time is small for these wines, while it is larger for red AOC wines. With a small marginal effect, it takes more years for the value of added $\mathrm{SO}_{2}$ to become positive (Table 6).

The robustness of the interaction between cellaring length and added $\mathrm{SO}_{2}$ across two groups of different quality suggests that this effect is not a result of omitted variables bias. The only non- $\mathrm{SO}_{2}$ variable that has a consistent effect on price across regressions for all groupings is the oak barrel dummy variable; an oak barrel has a positive effect on price, varying between 18 and $21 \%$.

For the next quality split, the sample was partitioned based on the existence of a Parker rating (Table 10). The model was also estimated for red wines without a nonParker rating. As before, the other possible groups (red Parker, white Parker, white non-Parker) do not contain enough observations to estimate the full model. The effect of added $\mathrm{SO}_{2}$ in the base group is significant and negative for the non-Parker and the red Non-Parker groupings. It is insignificant for the Parker grouping. The addition of $\mathrm{SO}_{2}$ has a positive effect on price for Demeter wines, although for red non-Parker wines, the positive effect does not outweigh the base negative effect of added $\mathrm{SO}_{2}$. In this model, the effect of added $\mathrm{SO}_{2}$ for wines certified by FNIVAB is significant; the addition has a negative effect on these wines when the sample only contains wines with a Parker rating.

Across regressions for all three groups, the interaction between added $\mathrm{SO}_{2}$ and intended cellaring length is statistically significant and positive. The effect is largest for red Non-Parker and smallest for the pooled red and white non-Parker. The significance of this variable across both the Parker and Non-Parker groups suggests that the effect of intended cellaring time on the effect of added $\mathrm{SO}_{2}$ is not driven by unobservable differences in quality.

As seen when partitioning by AOC status, the oak barrel indicator variable is the only variable with a coefficient that is significant across all groupings, yielding a positive effect on price.

\section{Conclusions}

From these results, several conclusions can be drawn. First, the addition of $\mathrm{SO}_{2}$ is generally associated with a decrease in price for red wines that are intended to be consumed immediately. Red wines with a Parker rating are the only exception to this; for these wines, the effect was negative but statistically insignificant. The myth that sulfites in wine cause headaches is largely associated with red wines, so it is not surprising that 
Table 10 Effects of Added $\mathrm{SO}_{2}$, Production Variables, Wine Characteristics, Indicators of Quality, and Winery Characteristics on Prices of Wines with and without Robert Parker Ratings and Prices of Red Wines without Robert Parker Ratings

\begin{tabular}{|c|c|c|c|c|c|c|}
\hline & \multicolumn{2}{|l|}{ Parker } & \multicolumn{2}{|c|}{ Non-Parker } & \multicolumn{2}{|c|}{ Red Non-Parker } \\
\hline & $\overline{\text { Coeff. }}$ & St. Error & $\overline{\text { Coeff. }}$ & St. Error & Coeff. & St. Error \\
\hline \multicolumn{7}{|l|}{$\mathrm{SO}_{2}$ Variables } \\
\hline $\mathrm{SO}_{2}$ & -0.282 & $(0.204)$ & $-0.275^{b}$ & $(0.134)$ & $-0.623^{b}$ & $(0.199)$ \\
\hline $\mathrm{SO}_{2} \times$ White & 0.170 & $(0.113)$ & 0.236 & $(0.184)$ & & \\
\hline $\mathrm{SO}_{2} \times$ Rosé & & & $0.534^{b}$ & $(0.206)$ & & \\
\hline $\mathrm{SO}_{2} \times \mathrm{FNIVAB}$ & $-0.576^{a}$ & $(0.299)$ & -0.042 & $(0.119)$ & 0.010 & $(0.151)$ \\
\hline $\mathrm{SO}_{2} \times$ Demeter & $0.210^{\mathrm{a}}$ & $(0.113)$ & 0.060 & $(0.129)$ & $0.498^{b}$ & $(0.238)$ \\
\hline $\mathrm{SO}_{2} \times \operatorname{Ln}$ (Intended Cellar) & $0.243^{\mathrm{a}}$ & $(0.142)$ & $0.180^{b}$ & $(0.057)$ & $0.321^{\mathrm{b}}$ & $(0.113)$ \\
\hline \multicolumn{7}{|l|}{ Production Variables } \\
\hline Ln(Intended Cellar) & -0.063 & $(0.130)$ & 0.082 & $(0.061)$ & -0.097 & $(0.107)$ \\
\hline Manual Harvest & 0.156 & $(0.160)$ & $0.184^{b}$ & $(0.065)$ & $0.163^{b}$ & $(0.072)$ \\
\hline Ferments Added & -0.174 & $(0.162)$ & 0.067 & $(0.064)$ & 0.038 & $(0.075)$ \\
\hline Sugar Added & $-0.440^{a}$ & $(0.245)$ & -0.215 & $(0.222)$ & 0.218 & $(0.160)$ \\
\hline Filtered & 0.060 & $(0.118)$ & -0.009 & $(0.074)$ & $-0.149^{b}$ & $(0.069)$ \\
\hline Oak Barrel & $0.335^{c}$ & $(0.080)$ & $0.140^{c}$ & $(0.032)$ & $0.168^{c}$ & $(0.040)$ \\
\hline Ln(Production) & -0.009 & $(0.043)$ & $-0.120^{c}$ & $(0.025)$ & $-0.067^{b}$ & $(0.034)$ \\
\hline \multicolumn{7}{|l|}{ Wine Characteristics } \\
\hline Ln(Aged) & 0.158 & $(0.228)$ & 0.055 & $(0.100)$ & $0.161^{b}$ & $(0.075)$ \\
\hline \% Alcohol & -0.038 & $(0.039)$ & $0.032^{\mathrm{a}}$ & $(0.018)$ & $0.046^{\mathrm{a}}$ & $(0.024)$ \\
\hline Sparkling & 0.061 & $(0.166)$ & $0.346^{c}$ & $(0.095)$ & $0.329^{b}$ & $(0.136)$ \\
\hline White & -0.145 & $(0.141)$ & -0.259 & $(0.226)$ & & \\
\hline Rosé & 0.267 & $(0.301)$ & $-0.484^{\mathrm{a}}$ & $(0.252)$ & & \\
\hline \multicolumn{7}{|l|}{ Indicators of Quality } \\
\hline Hachette & -0.073 & $(0.176)$ & -0.065 & $(0.069)$ & -0.034 & $(0.073)$ \\
\hline Hachette $\times$ Stars & -0.151 & $(0.129)$ & -0.028 & $(0.055)$ & -0.034 & $(0.067)$ \\
\hline Hachette CDC & 0.266 & $(0.195)$ & 0.031 & $(0.144)$ & 0.035 & $(0.120)$ \\
\hline $\mathrm{AOC}$ & 0.023 & $(0.095)$ & $0.241^{b}$ & $(0.088)$ & $0.146^{\mathrm{b}}$ & $(0.074)$ \\
\hline Grand Cru & 0.332 & $(0.218)$ & -0.075 & $(0.204)$ & $0.999^{c}$ & $(0.128)$ \\
\hline Villages & 0.216 & $(0.486)$ & -0.007 & $(0.124)$ & -0.041 & $(0.106)$ \\
\hline Parker Rating & -0.002 & $(0.069)$ & & & $0.019^{c}$ & $(0.004)$ \\
\hline \multicolumn{7}{|l|}{ Winery Characteristics } \\
\hline FNIVAB & $0.723^{b}$ & $(0.343)$ & & & 0.062 & $(0.167)$ \\
\hline Biodyvin & 0.093 & $(0.125)$ & & & 0.074 & $(0.256)$ \\
\hline Demeter & & & & & $-0.692^{b}$ & $(0.254)$ \\
\hline Ln(OrgExp) & -0.041 & $(0.080)$ & 0.169 & $(0.202)$ & -0.014 & $(0.040)$ \\
\hline Ln(Total Area) & -0.119 & $(0.119)$ & & & 0.011 & $(0.043)$ \\
\hline Controls for Variety, Region, Vintage & Yes & & Yes & & Yes & \\
\hline Constant & 3.048 & $(6.228)$ & $1.236^{\mathrm{c}}$ & $(0.359)$ & $1.684^{c}$ & $(0.388)$ \\
\hline N & 128 & & 414 & & 253 & \\
\hline
\end{tabular}


Table 10 Effects of Added $\mathrm{SO}_{2}$, Production Variables, Wine Characteristics, Indicators of Quality, and Winery Characteristics on Prices of Wines with and without Robert Parker Ratings and Prices of Red Wines without Robert Parker Ratings (Continued)

\begin{tabular}{lllc}
\hline $\mathrm{R}^{2}$ & 0.885 & 0.264 & 0.661 \\
Hausman Test Chi ${ }^{2}(61),(50),(56)$ & 22.15 & $89.26^{\mathrm{c}}$ & 48.46 \\
Model Type & Random Effects & Fixed Effects & Random Effects \\
\hline
\end{tabular}

a, b and ${ }^{c}$ indicate significance at the $10 \%, 5 \%$, and $1 \%$ level, respectively. Heteroskedastic robust standard errors reported in parentheses. Degrees of freedom for each regression are reported in parentheses for the Hausman Tests

there is a negative effect of added $\mathrm{SO}_{2}$ on red wines intended to be consumed immediately. For non-Biodyvin and non-FNIVAB white and rosé wines, the effect appears to be neutral or positive. This is likely driven by the likelihood of oxidation for these wines, and the lack of headaches generally experienced after drinking white and rosé wine.

For red, white, or rosé Biodyvin wines, the effect is negative for wines intended for immediate consumption. In general, the results suggest that Biodyvin wines command a price premium relative to other organic and biodynamic wines, potentially due to the tasting requirement of certification. These consumers may not view biodynamic wines as highly when $\mathrm{SO}_{2}$ is added, due to the perceived health effects of sulfites. Similarly, for some red and white FNIVAB wines, the effect is negative. However, red wines certified by Demeter experience a positive or less negative effect from added $\mathrm{SO}_{2}$. Demeter wines experience negative price effects from certification, regardless of sulfite content. If Demeter wines are viewed as being of lesser quality than the other eco-labels, consumers may perceive the need for sulfites to preserve the wine or Demeter wines may attract a different customer base that is unaware of the perceived negative consequences of added $\mathrm{SO}_{2}$.

While red wines that are intended to be consumed immediately may receive a lower price when $\mathrm{SO}_{2}$ is added, wines with longer intended cellaring times benefit from the addition of $\mathrm{SO}_{2}$, most likely due to the resultant decreased risk of oxidation from the preservative. Our results suggest that as intended cellaring time increases, the effect of added $\mathrm{SO}_{2}$ also increases, and the net effect will be positive after a given length of time, ranging from 2.21 to 34.95 years for red wines.

With respect to the U.S. organic wine-labeling dilemma, first, the applicability of these results must be considered. In general, the European organic market is larger than the American organic market. A higher percentage of agricultural land is under organic production in Europe, and a higher share of purchased food is certified organic in Europe (Agence Bio 2013; Green 2013). This implies that there is likely higher demand for organic wine in France than the U.S. This would potentially lead to higher prices for all organic wine sold in France, regardless of the addition of $\mathrm{SO}_{2}$. This analysis is concerned with the marginal effect of added $\mathrm{SO}_{2}$ on price, and the existence of an overall organic price premium in France does not imply a change in the marginal effect of added $\mathrm{SO}_{2}$. Such an effect would only result from a difference in consumer perceptions regarding added $\mathrm{SO}_{2}$. Both French and American consumers blame the sulfites in wine for their headaches (Gaiter and Brecher 2000, Remaud and Sirieix 2012). Consumer knowledge of the use of $\mathrm{SO}_{2}$ as a preservative may vary, but no evidence of this variation could be found in the literature. Assuming the same level of knowledge, which is likely to 
be the case across French and American consumers who intend to cellar their wines for extended periods of time, the results from this study will be applicable because the marginal effect of added $\mathrm{SO}_{2}$ will be similar in both markets. Further work should explore whether or not preferences for or against added $\mathrm{SO}_{2}$ and knowledge of added $\mathrm{SO}_{2}$ vary across countries.

Given that the marginal effect of added $\mathrm{SO}_{2}$ in the U.S. should be similar to that found here, there are two main implications for the U.S. market. First, regardless of the type of eco-certification or wine color, the price of wines that are intended to be cellared for longer periods of time benefits from the addition of $\mathrm{SO}_{2}$. Wineries producing such wines would likely benefit from the allowance of added $\mathrm{SO}_{2}$ in wines labeled as "organic". Second, the effect of added $\mathrm{SO}_{2}$ for wines intended to be consumed immediately varies depending on wine color and type of eco-label.

Future work that explores preferences regarding added $\mathrm{SO}_{2}$ among consumers of American organic wines and wines made with organic grapes would shed further light on the potential economic benefits of altering label regulation for wines consumed shortly after purchase.

\section{Endnotes}

${ }^{1}$ The addition of sugar is regulated both in the U.S. and in Europe (Bureau of Alcohol, Tobacco and Firearms, 1999; Meloni and Swinnen, 2012).

${ }^{2}$ From equation (1), the $\mathrm{SO}_{2}$ variables could be interacted with all other variables. Such a model, however, would contain an excessive number of independent variables, impeding estimation of the model. Consequently, the effect of added $\mathrm{SO}_{2}$ is assumed to be separable.

${ }^{3}$ Most wineries submit their wines to the website once and only report those wines they are selling at the time of the reporting, limiting the range of vintages reported by any single winery.

${ }^{4}$ For all models, both random effects and fixed effects models were estimated. A Hausman test was performed to test for correlation between $u_{j}$ and the independent variables. Only the model preferred by the Hausman test is reported.

${ }^{5}$ Prior to Regulation (EU) No. 203/2012, all European wine was subject to limits on sulfite concentrations. The new regulation sets separate limits on organic wine that are $30-50 \mathrm{mg} / \mathrm{L}$ less than conventional standards. This amounts to limits that average approximately $80 \%$ of the limits on conventional wine. These new limits on European organic wine are similar to the limits on Demeter and FNIVAB certified wine used in the dataset.

${ }^{6}$ While the country-specific organic certifications will now be subsumed by the EU standard under Regulation (EU) No. 203/2012, Demeter and Biodyvin certifications will continue because they indicate biodynamic production, not just organic production.

${ }^{7}$ SIVCBD is the Syndicat International des Vignerons en Culture Bio-Dynamique, an association of French biodynamic winemakers.

${ }^{8}$ The p-value on a two-sided test of the coefficient in the regression containing all AOC wines is 0.12 , so while it does not meet the criterion for significance, it should be noted that if a 1-sided test is used, it would be significant at the $6 \%$ level. 


\section{Competing interests}

The authors declare that they have no competing interests.

Received: 23 January 2015 Accepted: 13 July 2015

Published online: 22 July 2015

\section{References}

Agence Bio (2013) Chapter 4: La Bio en France de la Production a la Consumption. In Key Data on Organic Farming. Available at: http://www.agencebio.org/sites/default/files/upload/documents/4_Chiffres/BrochureCC/ CC2013_chap4_France.pdf.

Alcohol and Tobacco Tax and Trade Board [ATTTB] (2014) Labeling Organic Wine. Available at: http://www.ttb.gov/alfd/ alfd_organic.shtml.

Alcohol and Tobacco Tax and Trade Board [ATTTB] (2006) Major Food Allergen Labelling for Wines, Distilled Spirits, and Malt Beverages. Federal Register 71(143):42260-42270

Ali HH, Nauges C (2007) The Pricing of Experience Goods: The Example of En Primeur Wine. American Journal of Agricultural Economics 89(1):91-103

Ashenfelter O, Storchmann K (2010) Using Hedonic Models of Solar Radiation and Weather to Assess the Economic Effect of Climate Change: The Case of Mosel Valley Vineyards. Review of Economics and Statistics 92(2):333-349

Bachelot F (2010) Guide Hachette des Vins. Hachette, Paris

Biodyvin (2009) Biodyvin Wine Making Charter. Available at: http://www.biodyvin.com/medias/cvS61pAqjF7g/files/ en-chartevinification2009.pdf

Biodyvin (2012) How to Become a Member. Available at: http://www.biodyvin.com/en/become-a-member/ how-to-become-a-member.html

Bureau of Alcohol, Tobacco and Firearms (1999) Title 27, Chapter 1, Subchapter A, Section 24.177-Chaptalization (Brix Adjustment). Available at: http://www.gpo.gov/fdsys/granule/CFR-1999-title27-vol1/CFR-1999-title27-vol1-sec24-177/ content-detail.html

Charters S, Lockshin L, Unwin T (1999) Consumer Responses to Wine Bottle Back Labels. Journal of Wine Research 10(3):183-195

Combris P, Lecocq S, Visser M (1997) Estimation of a Hedonic Price Equation for Bordeaux Wine: Does Quality Matter? The Economic Journal 107(441):390-402

Costanigro M, McCluskey JJ, Mittelhammer RC (2007) Segmenting the Wine Market Based on Price: Hedonic Regression when Different Prices Mean Different Products. Journal of Agricultural Economics 58(3):454-466

Costanigro M, Appleby C, Menke S (2014) The Wine Headache: Consumer Perceptions of Sulfites and Willingness to Pay for Non-Sulfited Wines. Food Quality and Preference 31:81-89

Cross R, Plantinga AJ, Stavins RN (2011) What is the Value of Terroir? American Economic Review 11(3):152-156

Delmas MA, Grant LE (2010) Eco-Labeling Strategies and Price-Premium: The Wine Industry Puzzle. Business \& Society 20(10):1-39

Demeter (2011) International Demeter Standards- Processing. Available at: http://www.demeter.net/certification/ standards/processing.

Federation Nationale Interprofessionnelle des Vins de l'Agriculture Biologique [FNIVAB] (2011) Charter Wine Bio. Available at: http://www.ers.usda.gov/amber-waves/2013-october/growth-patterns-in-the-us-organicindustry. aspx\#.VagHuUVH04s.

Gaiter DJ, Brecher J (2000) Why Do I Get Headaches from Wine? The Wall Street Journal. Available at: http://guides.wsj.com/wine/wine-\%20tips-and-tricks/why-do-i-get-headaches-from-wine/.

Green C (2013) Growth Patterns in the U.S. Organic Industry. USDA Amber Waves. Available at: http://www.ers.usda.gov/ amber-waves/2013-october/growth-patterns-in-the-us-organic-industry.aspx\#.U1_ff8eZ78F.

Haeger JW, Storchmann K (2006) Prices of American Pinot Noir Wines: Climate Craftsmanship, Critics. Agricultural Economics 35:67-78

IFOAM EU Group (2013) EU Rules for Organic Wine Production- Background, Evaluation and Further Sector Development., Available at: http://www.itr.si/uploads/LW/AJ/LWAJRgGe_kylvigPDidvmg/ ifoameu_reg_wine_dossier_201307.pdf

Jarisch R, Wantke F (1996) Wine and Headache. International Archives of Allergy and Immunology 110:7-12

Jonis M, Monnier MC, Schmid O, Micheloni C, Hofmann U (2008) Analysis of Regulatory Framework and Standards Applied to Organic Wine-Making in Europe, Paper Presented at $16^{\text {th }}$ IFOAM Organic World Congress, Modena, Italy, June 16-20, 2008

Lancaster KJ (1966) A New Approach to Consumer Theory. Journal of Political Economy 74(2):132-157

Lecocq S, Visser M (2006) What Determines Wine Prices: Objective vs. Sensory Characteristics. Journal of Wine Economics 1(1):42-56

Lester MR (1995) Sulfite Sensitivity: Significance in Human Health. Journal of the American College of Nutrition 14(3):229-232

Meloni G, Swinnen J (2012) The Political Economy of European Wine Regulations. LICOS Centre for Institutions and Economics Performance, LICOS Discussion Paper Series, 320/2012

Morethanorganic (2015) Natural Wine Logos and Labels. Available at: http://www.morethanorganic.com/ organic-labelling.

Mueller S, Lockshin L, Saltman Y, Blanford J (2010) Message on a Bottle: The Relative Influence of Wine Back Label Information on Wine Choice. Food Quality and Preference 21:22-32

National Organic Standards Board [NOSB] (2011a). Formal Recommendation by the National Organic Standards Board (NOSB) to the National Organic Program (NOP). Available at: http://www.ams.usda.gov/AMSv1.0/ getfile?dDocName=STELPRDC5097105.

Oczkowski E, Doucouliagos, H (2014) Wine Prices and Quality Ratings: A Meta-Regression Analysis. American Journal of Agricultural Economics 1-19, doi:10.1093/ajae/aau057. 
Remaud H, Sirieix L (2012) Eco-Friendly Wines As Opposed to Conventional Wine in Australia and France: From Consumers' Perception to Marketing Implications. Decisions Marketing 67:23-35

Reuter J (2009) Does Advertising Bias Product Reviews? An Analysis of Wine Ratings. Journal of Wine Economics 4(2):125-151

Rosen S (1974) Hedonic Prices and Implicit Markets: Product Differentiation in Pure Competition. Journal of Political Economy 82(1):34-55

Schiefer J, Fischer C (2008) The Gap Between Wine Expert Ratings and Consumer Preferences: Measures, Determinants and Marketing Implications. International Journal of Wine Business. Research 20(4):335-351.

Siegel RD (2010) Petition to Amend Annotation for Sulfur Dioxide, in National List, Section 205.605(b). Available at: http://www.ams.usda.gov/AMSv1.0/getfile?dDocName=STELPRDC5085633.

Thomas A, Pickering G (2005) X-it: Gen-X and Older Wine Drinker Comparisons in New Zealand. International Journal of Wine Marketing 17(2):30-48

United States Department of Agriculture National Organic Program [USDA NOP] (2011) Sulfur Dioxide Handling. Technical Evaluation Report. Available at: http://www.ams.usda.gov/AMSv1.0/ getfile?dDocName=STELPRDC5094931.

Viana RC, Rodrigues LL (2007) What Determines Port Wine Prices. Journal of Wine Economics 2(2):203-212

Waterhouse AL (2002) Wine Phenolics. Annals New York Academy of Sciences 957:21-36

Yang N, McCluskey JJ, Brady MP (2012) The Value of Good Neighbors: A Spatial Analysis of the California and Washington State Wine Industries. Land Economics 88(4):674-684

\section{Submit your manuscript to a SpringerOpen ${ }^{\circ}$ journal and benefit from:}

- Convenient online submission

- Rigorous peer review

- Immediate publication on acceptance

- Open access: articles freely available online

- High visibility within the field

- Retaining the copyright to your article

Submit your next manuscript at $\boldsymbol{\nabla}$ springeropen.com 